\title{
Universiteit
}

Leiden

The Netherlands

\section{Anticancer opportunities at every stage of chemokine function}

Ortiz Zacarías, N.V.; Bemelmans, M.P.; Handel, T.M.; Visser, K.E. de; Heitman, L.H.

\section{Citation}

Ortiz Zacarías, N. V., Bemelmans, M. P., Handel, T. M., Visser, K. E. de, \& Heitman, L. H. (2021). Anticancer opportunities at every stage of chemokine function. Trends In Pharmacological Sciences. doi:10.1016/j.tips.2021.08.001

Version: $\quad$ Publisher's Version

License: $\quad$ Creative Commons CC BY-NC-ND 4.0 license

Downloaded from: https://hdl.handle.net/1887/3216877

Note: To cite this publication please use the final published version (if applicable). 


\title{
Trends in Pharmacological Sciences
}

\section{Anticancer opportunities at every stage of chemokine function}

\author{
Natalia V. Ortiz Zacarías, ${ }^{1,2,6}$ Martijn P. Bemelmans, ${ }^{1,6}$ Tracy M. Handel, ${ }^{3}$ Karin E. de Visser, ${ }^{2,4,5}$ and \\ Laura H. Heitman ${ }^{1,2, \star}$
}

The chemokine system, comprising 48 chemokines and 23 receptors, is critically involved in several hallmarks of cancer. Yet, despite extensive efforts from the pharmaceutical sector, only two drugs aimed at this system are currently approved for clinical use against cancer. To date, numerous pharmacological approaches have been developed to successfully intervene at different stages of chemokine function: (i) chemokine availability; (ii) chemokine-glycosaminoglycan binding; and (iii) chemokine receptor binding. Many of these strategies have been tested in preclinical cancer models, and some have advanced to clinical trials as potential anticancer therapies. Here we will review the strategies and growing pharmacological toolbox for manipulating the chemokine system in cancer, and address novel methods poised for future (pre)clinical testing.

\section{Chemokines and their receptors in cancer}

Currently, 48 chemokines (chemotactic cytokines) and 23 chemokine receptors are documented as members of the chemokine superfamily [1]. Together, they function in a concerted manner to govern the migration and localization of all immune cells in the human body [2]. Accordingly, the chemokine system forms a highly relevant therapeutic target for a plethora of immune and inflammation-related disorders. In particular, the chemokine system is highly involved in cancer, with reported roles in almost all hallmarks of the disease, such as promoting angiogenesis, metastasis, and an immunosuppressive tumor microenvironment (TME) (see Glossary) (Box 1) [3]. Chemokines and their receptors can be expressed by many types of cells within the TME, including cancer cells, endothelial cells, and immune cells. From here, chemokines can regulate leukocyte recruitment to the TME, as well as leukocyte differentiation or polarization, which can lead to an immunosuppressive TME that favors tumor growth. In addition, chemokine signaling on tumor cells can directly promote cancer cell proliferation, survival, invasiveness and metastasis, cancer stem cell-like phenotypes, and angiogenesis [4-8] (Box 1). However, antitumor roles have also been described $[4,7,8]$, which adds a layer of complexity when targeting this system. To date, only two drugs targeting the chemokine system are approved for clinical use in cancer: Plerixafor (anti-CXCR4) and Mogamulizumab (anti-CCR4), both against hematological malignancies. The paucity of clinically-approved anticancer drugs aimed at this system provides an impetus to review the current approaches to pharmacologically modulate the chemokine system and assess their respective (dis)advantages to aid in the rational design of future anticancer therapies.

Targeting the chemokine system: from chemokine secretion to downstream receptor signaling

Chemokine function involves different stages, each of which provides opportunities for therapeutic intervention (Figure 1). First, chemokines are secreted by a variety of cells either in homeostasis or upon induction by inflammatory stimuli. While some of these chemokines remain inside the underlying tissue, a fraction moves to the luminal surface of endothelial cells forming the blood

\section{Highlights}

The chemokine system has emerged as a relevant target in immune-oncology, with roles in most hallmarks of cancer.

Therapeutic targeting of this system can be achieved by interfering with chemokines, chemokine receptors, or glycosaminoglycans.

Many therapies aimed at the chemokine system are currently under clinical oncological investigation, including monoclonal antibodies targeting chemokines and their receptors, glycomimetics, and various peptides or small-molecule antagonists for chemokine receptors.

Other strategies showed preclinical anticancer value and appear poised for clinical testing, including nanobodies, small-molecule chemokine inhibitors, engineered chemokines, pepducins, siRNA, and biased ligands.

The emergence of chemokine receptor antagonists with novel mechanisms of action may prove more effective in the clinic.

${ }^{1}$ Division of Drug Discovery and Safety, Leiden Academic Centre for Drug Research, Leiden University, Leiden, The Netherlands

${ }^{2}$ Oncode Institute, Leiden University, Leiden, The Netherlands

${ }^{3}$ University of California San Diego, Skaggs School of Pharmacy and Pharmaceutical Sciences,

La Jolla, CA, USA

${ }^{4}$ Division of Tumor Biology and Immunology, Netherlands Cancer Institute, Amsterdam, The Netherlands

${ }^{5}$ Department of Immunology, Leiden University Medical Centre, Leiden, The Netherlands

${ }^{6}$ These authors contributed equally to this work 
vessel wall, where they bind glycosaminoglycans (GAGs) with varying degrees of affinity $[9,10]$. These chemokine-GAG interactions prevent chemokines from rapidly diffusing away in the circulation and are thus key for forming a localized concentration gradient that directs leukocyte migration toward the site of secretion [9,10]. Patrolling leukocytes (or cancer cells) expressing a corresponding receptor then interact with these chemokines, eliciting multiple downstream signaling cascades and distinct biological effects, some of which are cancer-related (Box 1). In the following sections, we discuss the different strategies that interfere with these three key stages of chemokine function in cancer: (i) chemokine availability; (ii) chemokine-GAG interactions; and (iii) chemokine-receptor binding. Given the magnitude of the chemokine system, this work delineates a selection of exemplary cases rather than a comprehensive list of all (pre)clinical therapies targeted at the chemokine system in cancer. An overview of the discussed anticancer strategies is provided in Table 1 (Key table).

\section{Interfering with chemokine availability \\ Biologics}

One strategy for interfering with tumorigenic chemokine signaling is to preclude the presence of chemokines at the tumor site by neutralization with monoclonal antibodies (mAbs). mAbs offer many desirable features as therapeutics, including a long serum half-life, high selectivity and specificity, and indirect mechanisms of action such as antibody-dependent cellmediated/cellular cytotoxicity (ADCC) or complement-dependent cytotoxicity (CDC)

\author{
${ }^{\star}$ Correspondence: \\ I.h.heitman@lacdr.leidenuniv.nl \\ (L.H. Heitman).
}

\begin{abstract}
Box 1. The chemokine system in various hallmarks of cancer
Many chemokines and chemokine receptors play key roles in various hallmarks of cancer (Figure I).
\end{abstract}

\title{
Sustaining cancer cell proliferation
}

Chemokines can directly activate downstream signaling cascades to enhance tumor cell proliferation, such as PI3K/AKT/NF-KB by CXCL16, MAPK/ERK by CCL5, and the STAT3 pathway by CCR5 and CCR7 [3,5]. They can also indirectly induce proliferation by transactivation of epidermal growth factor receptor (EGFR), as reported for CXCR4/ACKR3 [89]. Conversely, CXCL14 can suppress proliferative signaling in various cancer types [4].

\section{Altering stress response to favor cell survival}

Cell survival can be enhanced by modulation of proapoptotic and antiapoptotic proteins. For example, CCR5 was found to upregulate proapoptotic proteins and downregulate antiapoptotic proteins via activation of NF-kB [3]. Similarly, activation of CXCR4, CCR3, CCR7, and CCR8 induces inactivation of proapoptotic proteins via the ERK pathway. Chemokine signaling can also protect cancer cells from autophagic death, such as CXCR4 via the PI3K-mTOR pathway. Finally, chemokine receptors can interact with tumor suppressors, such as TP53, to regulate their anticancer activity [3].

\section{Inducing angiogenesis}

Chemokines, such as CXCL8 and CCL2, can promote tumor angiogenesis by directly targeting vascular endothelial cells and promoting their survival, synergizing with vascular endothelial growth factor, or recruiting endothelial progenitor cells. In general, most chemokines have been reported to stimulate angiogenesis; however CCL21, CXCL4, CXCL9, CXCL10, CXCL11, and CXCL14 appear to inhibit it [3,5,6].

\section{Promoting invasion and metastasis}

Chemokine signaling can regulate cancer cell invasiveness and metastasis by guiding cell migration and inducing epithelial-mesenchymal transition (EMT). For instance, CXCR4 expression is correlated with metastasis to the bone marrow, lymph nodes, and lungs, which produce high levels of CXCL12 [6,89]. Similarly, the CCL19/ CCL21-CCR7 signaling axis is fundamental for lymph node metastasis [6,61]. CCL2, CCL18, and CXCL8 are examples of chemokines that induce EMT [4].

\section{Immune modulation and the TME}

The chemokine system can regulate the immune system to avoid cancer cell destruction or induce tumor-promoting inflammation. For instance, the CXCL16-CXCR6 axis drives the differentiation of macrophages toward a tumor-promoting phenotype. CCL2, CCL5, and CXCL12 recruit immunosuppressive leukocytes, such as tumorassociated macrophages and myeloid-derived suppressor cells [7]. Conversely, the CXCL9/CXCL10-CXCR3 axis can enhance tumor immune destruction [4].

\section{Metabolic rewiring}

The CXCL12-CXCR4 axis regulates expression and secretion of phosphoglycerate kinase 1, an enzyme involved in metabolic reprogramming from oxidative phosphorylation to glycolysis [3]. 


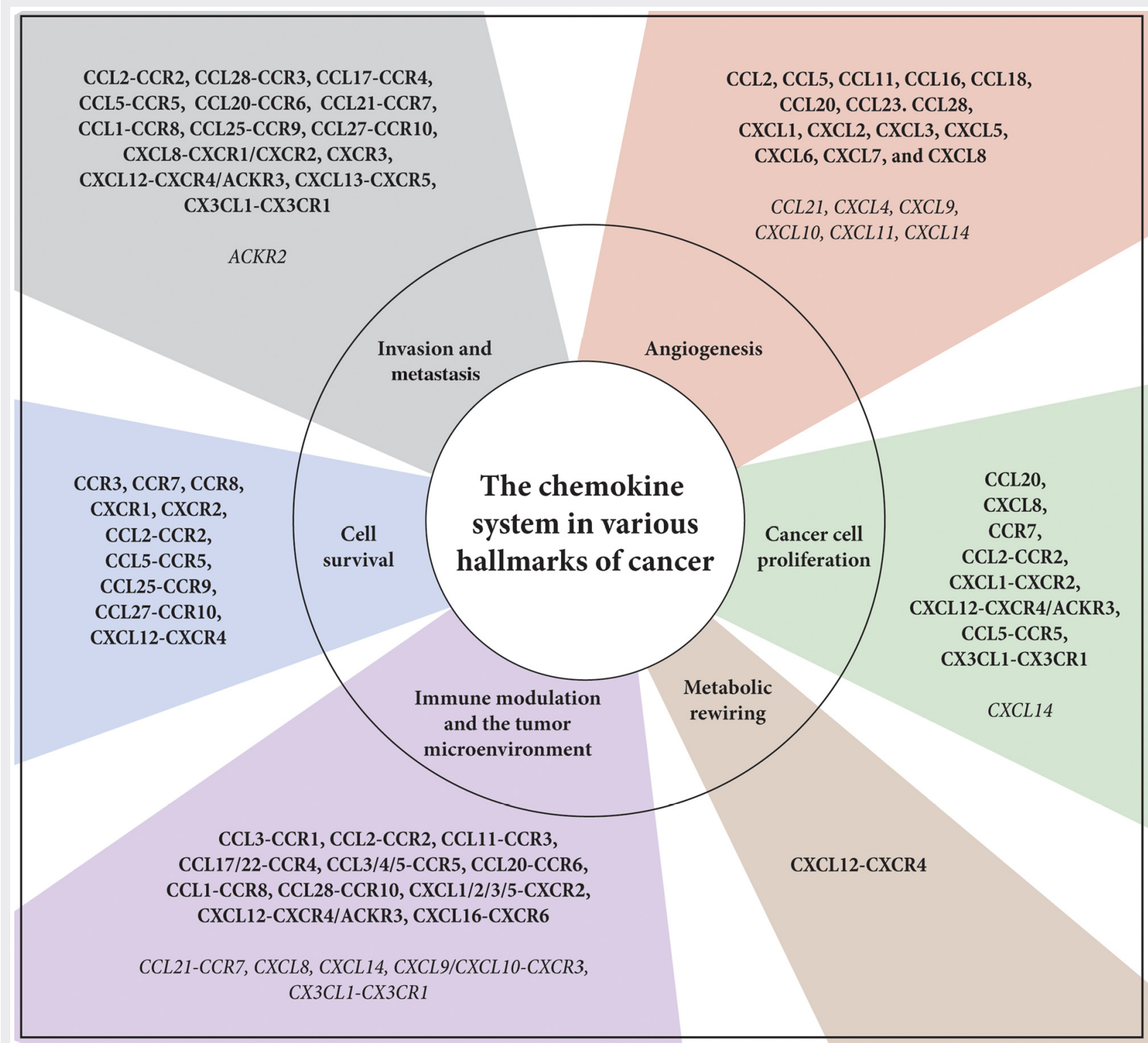

Trends in Pharmacological Sciences

Figure I. Examples of chemokines, chemokine receptors, or chemokine-receptor pairs that have been reported to play protumor (bold) and antitumor (italics) roles in various hallmarks of cancer.

$[11,12]$. Chemokine-neutralizing mAbs have shown some success in preclinical cancer models with reduction of TME tumorigenic signaling, tumor growth, angiogenesis, and metastasis $[13,14]$. For example, blocking CCL1-CCR8 signaling with an anti-CCL1 antibody attenuated the immunosuppressive function of regulatory $T$ cells $\left(T_{\text {regs }}\right)$ in the TME, without inhibiting effector T cell function in a mouse model of breast cancer [13]. In addition, treatment with an anti-CXCL1 $\mathrm{mAb}$, which prevents signaling mainly via CXCR2, inhibited angiogenesis, reduced tumor growth, 


\section{(A) (Patho-)physiological signaling}

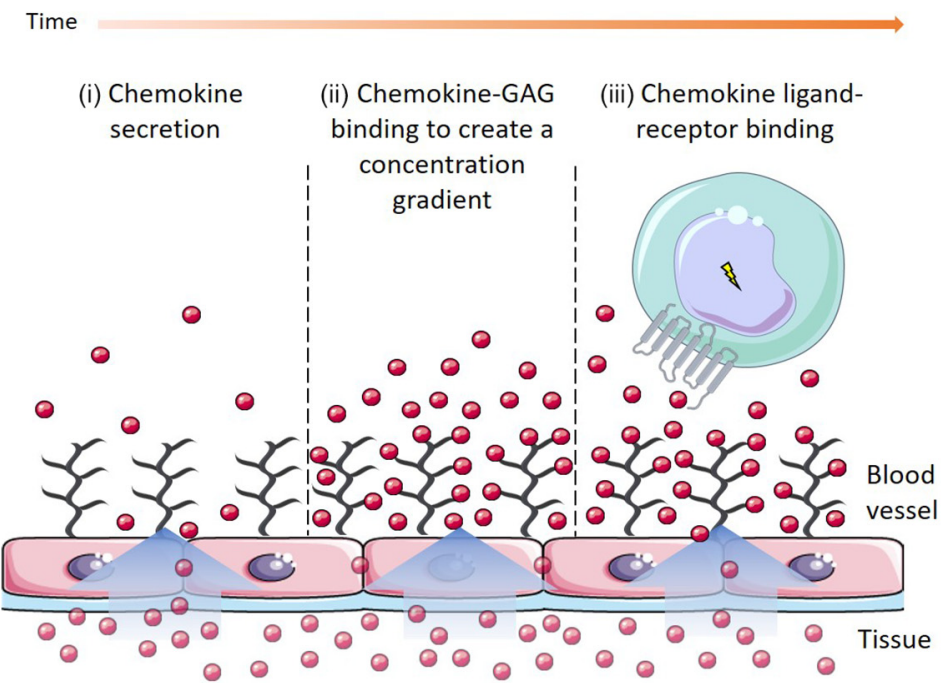

(B) Therapeutic modulation at each stage of chemokine functioning

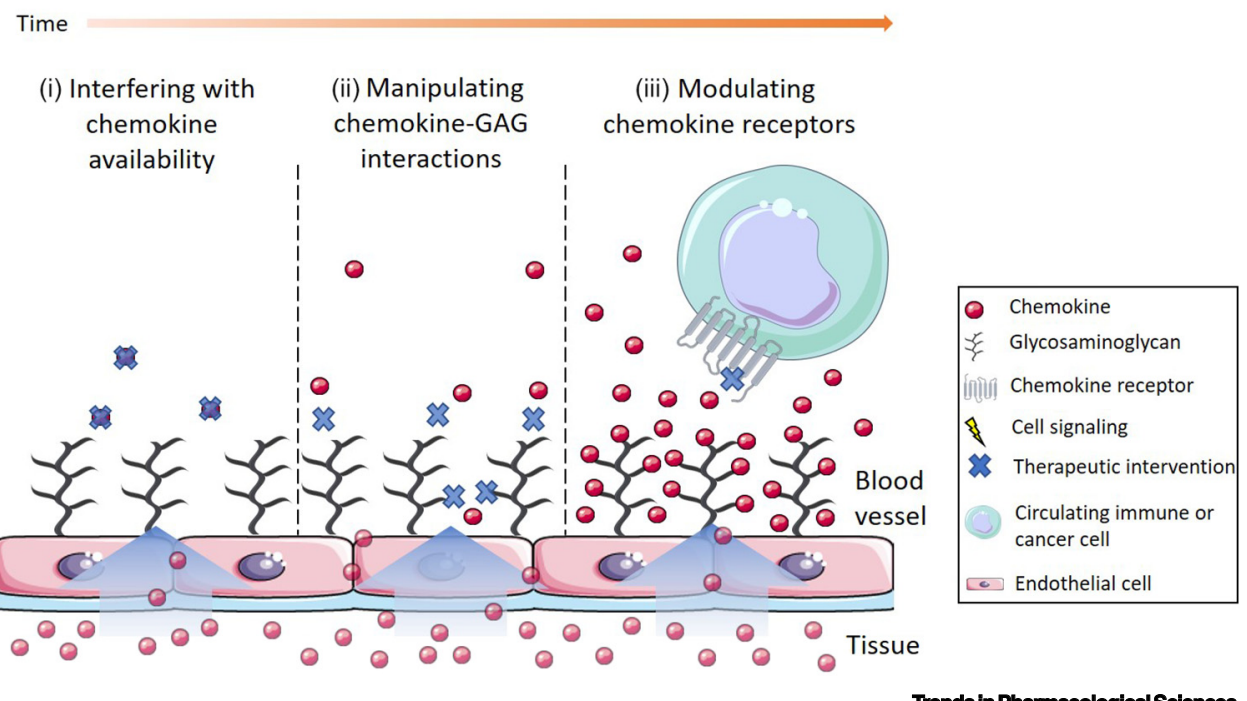

Figure 1. Avenues for therapeutic intervention in chemokine ligand-receptor signaling. (A) Schematic visualization of the steps involved in chemokine ligand-receptor signaling over time. (i) chemokine secretion; (ii) chemokineglycosaminoglycan (GAG) binding to create a concentration gradient; and (iii) chemokine ligand-receptor binding. (B) Schematic visualization of how therapies can interfere with these steps. Therapies can: (i) intervene with chemokine availability; (ii) prevent chemokines from binding to GAGs and thus, precluding a chemokine gradient; or (iii) block chemokine receptors to prevent chemokine binding and (oncogenic) downstream signaling. This figure was created using elements from Servier medical art.

and induced apoptosis in mice bearing bladder and prostate tumors [14]. The CXCL8-CXCR1/ CXCR2 signaling axis has also been targeted with chemokine antibodies. In fact, the antiCXCL8 antibody BMS-986253 became the first chemokine antibody to undergo clinical trials in patients with advanced solid tumors. A Phase I study showed the antibody to be well-tolerated and effective at reducing serum CXCL8 levels [15]. BMS-986253 is currently under clinical investigation as co-therapy with anti-programmed cell death (PD)-1 antibody Nivolumab in advanced

\section{Glossary}

Allosteric binding site: any site(s) in a protein where molecules can bind other than the binding site of the endogenous ligand(s)/substrate(s).

Antibody-dependent cell-mediated/ cellular cytotoxicity (ADCC): a mechanism whereby effector immune cells bind to the Fc region of an antibodytumor cell complex and subsequently secrete factors leading to lysis of the tumor cell.

Biased signaling: preferred activation of one signal transduction pathway over another upon a ligand binding to a receptor

Chemotaxis: directed movement of cells toward a molecular concentration gradient (e.g., of chemokines).

Complement-dependent cytotoxicity (CDC): a mechanism whereby the complement protein $\mathrm{C} 1 \mathrm{q}$ binds to the Fc region of an antibodytumor cell complex to induce tumor cell lysis through the complement pathway. Glycosaminoglycans (GAGs): long, linear, and highly charged polysaccharides, that can occur as soluble entities in the extracellular matrix or in a bound form as part of endothelial cell-surface proteoglycans that, in turn, form the glycocalyx.

Insurmountable antagonism: the ability of an antagonist to decrease the maximum level of receptor activation despite a high concentration of the endogenous agonist, as well as to possibly decrease the agonist's potency.

Monoclonal antibodies (mAbs): antibodies produced by clones of a single B-lymphocyte fused with an immortal myeloma cell. These biologics comprise two antigen-binding fragments (Fab) and a fragment crystallizable region ( $\mathrm{Fc}$ ). Multitarget ligands: molecules that can bind more than one protein target with reasonable selectivity (i.e., other than unintended promiscuous target binding).

Nanobodies: antibodies consisting of only a single antigen-binding fragment, derived from camelids. Due to their single-domain nature, they are much smaller than monoclonal antibodies.

Orthosteric binding site: the site in a protein where its endogenous ligand(s)/ substrate(s) bind(s).

Pepducins: lipid-linked peptides with an amino acid sequence derived from one of the intracellular loops or the C-terminus of the target $G$ protein-coupled receptor (GPCR). The lipid moiety 


\section{Key table}

Table 1. Overview of discussed (pre)clinically tested strategies to modulate the chemokine system in cancer

\begin{tabular}{|c|c|c|c|c|}
\hline Target & Name/type of therapy & $\begin{array}{l}\text { Model/latest stage } \\
\text { clinical trial }\end{array}$ & Key result/comment & Refs/identifiers \\
\hline \multicolumn{5}{|c|}{ Chemokine-oriented therapies } \\
\hline CCL1 & a-CCL1 (antibody) & $\begin{array}{l}\text { In vivo BALB-neuT } \\
\text { mouse TUBO model } \\
\text { of breast cancer }\end{array}$ & $\begin{array}{l}\text { Reduced } \\
\text { immunosuppressive } \\
\text { function and de novo } \\
\text { conversion of } \mathrm{T}_{\text {regs }}\end{array}$ & [13] \\
\hline CCL2 & Carlumab (antibody) & $\begin{array}{l}\text { Phase II clinical trials } \\
\text { (castrate-resistant } \\
\text { prostate cancer) }\end{array}$ & $\begin{array}{l}\text { Lack of antitumor activity } \\
\text { and elevated CCL2 upon } \\
\text { therapy cessation }\end{array}$ & [25] \\
\hline CCL18 & $\begin{array}{l}\text { SMC-21598 (small } \\
\text { molecule) }\end{array}$ & $\begin{array}{l}\text { In vivo NOD-SCID } \\
\text { mouse MDA-MB-231 } \\
\text { model of breast } \\
\text { cancer }\end{array}$ & $\begin{array}{l}\text { Reduced lung metastasis } \\
\text { but not tumor growth }\end{array}$ & [26] \\
\hline CXCL1 & HL2401 (antibody) & $\begin{array}{l}\text { In vitro/in vivo, bladder } \\
\text { (T24) and prostate } \\
\text { (DU145, PC3) cancer } \\
\text { cells, xenograft mouse } \\
\text { models }\end{array}$ & $\begin{array}{l}\text { Inhibited angiogenesis } \\
\text { and proliferation, and } \\
\text { induced apoptosis in vivo. } \\
\text { Inhibited cancer cell } \\
\text { proliferation and invasion } \\
\text { in vitro }\end{array}$ & [14] \\
\hline CXCL8 & $\begin{array}{l}\text { BMS-986253 } \\
\text { (antibody, a.k.a. } \\
\text { HuMax-IL8) }\end{array}$ & $\begin{array}{l}\text { Phase I/Il clinical trials } \\
\text { (advanced cancers, } \\
\text { hormone-sensitive } \\
\text { prostate cancer, } \\
\text { non-small cell lung } \\
\text { cancer, hepatocellular } \\
\text { carcinoma, head and } \\
\text { neck squamous cell } \\
\text { carcinoma) }\end{array}$ & $\begin{array}{l}\text { Currently ongoing. In } \\
\text { combination with } \\
\text { anti-PD1 antibody, } \\
\text { Nivolumab, luteinizing } \\
\text { hormone-releasing } \\
\text { hormone antagonist, or } \\
\text { anti-CTLA-4 antibody }\end{array}$ & $\begin{array}{l}\text { NCT03400332, } \\
\text { NCT03689699, } \\
\text { NCT04050462, } \\
\text { NCT04848116, } \\
\text { NCT04123379 }\end{array}$ \\
\hline CXCL10 & 3NB12 (nanobody) & $\begin{array}{l}\text { In vitro MDA-MB-231 } \\
\text { mouse model of breast } \\
\text { cancer }\end{array}$ & Reduced chemotaxis & [17] \\
\hline CXCL11 & $\begin{array}{l}\text { 11B1 and 11B7 } \\
\text { (nanobodies) }\end{array}$ & $\begin{array}{l}\text { In vitro mouse L1.2 } \\
\text { model of precursor } \\
\text { B cell lymphoma }\end{array}$ & Reduced chemotaxis & [18] \\
\hline CXCL12 & 1A4 (nanobody) & $\begin{array}{l}\text { In vitro mouse L1.2 } \\
\text { model of precursor } \\
\text { B cell lymphoma }\end{array}$ & Reduced chemotaxis & [18] \\
\hline \multicolumn{5}{|c|}{ Glycosaminoglycan-oriented therapies } \\
\hline $\mathrm{CCL}^{\mathrm{a}}$ & $\begin{array}{l}\text { OTR } 4120 \text { and } \\
\text { OTR4131 } \\
\text { (glycomimetic) }\end{array}$ & $\begin{array}{l}\text { In vitro Huh7 and } \\
\text { Hep3B hepatocellular } \\
\text { carcinoma model }\end{array}$ & $\begin{array}{l}\text { Reduced CCL5-induced } \\
\text { tumor cell migration }\end{array}$ & [30] \\
\hline $\mathrm{CXCL} 12^{\mathrm{a}}$ & $\begin{array}{l}\text { RGTA (several } \\
\text { glycomimetics) }\end{array}$ & $\begin{array}{l}\text { In vitro Huh7 model of } \\
\text { hepatocellular } \\
\text { carcinoma }\end{array}$ & $\begin{array}{l}\text { Reduced chemotaxis and } \\
\text { anchorage-independent } \\
\text { cell growth }\end{array}$ & [31] \\
\hline $\begin{array}{l}\text { CXCL12, } \\
\text { VEGF-A, FGF2, } \\
\text { and P-selectin }{ }^{\mathrm{a}}\end{array}$ & $\begin{array}{l}\text { M402 (glycomimetic, } \\
\text { a.k.a. Necuparanib) }\end{array}$ & $\begin{array}{l}\text { Phase II clinical trial } \\
\text { (primary metastatic } \\
\text { pancreatic cancer) }\end{array}$ & $\begin{array}{l}\text { In combination with } \\
\text { chemotherapy. } \\
\text { Insufficiently } \\
\text { improved clinical } \\
\text { outcome }\end{array}$ & [35] \\
\hline $\begin{array}{l}\text { CXCR4- and } \\
\text { E-selectin } \\
\text { specific }^{2}\end{array}$ & $\begin{array}{l}\text { GMl-1359 } \\
\text { (glycomimetic) }\end{array}$ & $\begin{array}{l}\text { Phase lb clinical trials } \\
\text { (metastatic breast } \\
\text { cancer) }\end{array}$ & Currently ongoing & NCT04197999 \\
\hline
\end{tabular}

(continued on next page) becomes tethered in the cell membrane and anchors the peptide at the intracellular binding site of the target GPCR.

Peptibodies: one or more peptides fused to a fragment crystallizable region derived from an antibody to enhance the circulation half-life of the peptide(s). Fusion of multiple peptides enables multitarget binding.

Small interfering ribonucleic acids (siRNAs): short-length single or double-stranded RNA molecules that can prevent the expression of a target gene. Tumor-associated macrophages (TAMs): macrophages that are present in the tumor microenvironment. They are derived from monocytes that are recruited to the tumor microenvironment, or from tissue-resident macrophages. These macrophages become polarized to a protumorigenic phenotype by the cues from this environment.

Tumor microenvironment (TME): the immediate surroundings of cancer cells, including blood vessels, infiltrating immune cells, fibroblasts, extracellular matrix, epithelial cells, and other (possibly tumor-produced) extracellular signaling factors. Cancer cells are influenced by the TME, for instance, in their development and response to therapy. 
Table 1. (continued)

\begin{tabular}{|c|c|c|c|c|}
\hline Target & Name/type of therapy & $\begin{array}{l}\text { Model/latest stage } \\
\text { clinical trial }\end{array}$ & Key result/comment & Refs/identifiers \\
\hline $\begin{array}{l}\text { GAGs } \\
\text { (syndecan-4) }\end{array}$ & $\begin{array}{l}\text { dnCCL2-HSA } \\
\text { (modified chemokine) }\end{array}$ & $\begin{array}{l}\text { In vivo C57BL/6 } \\
\text { mouse MC-38, 3LL, } \\
\text { and LLC1 models of } \\
\text { colon and lung cancer }\end{array}$ & $\begin{array}{l}\text { Significantly reduced } \\
\text { lung metastasis }\end{array}$ & [29] \\
\hline $\begin{array}{l}\text { GAGs (heparin, } \\
\text { heparan sulfate) }\end{array}$ & $\begin{array}{l}\text { CXCL12a (modified } \\
\text { chemokine) }\end{array}$ & $\begin{array}{l}\text { In vivo SCID mouse } \\
\text { LMD231 model, } \\
\text { lung-metastasized } \\
\text { breast cancer }\end{array}$ & $\begin{array}{l}\text { Significant reduction of } \\
\text { liver metastasis }\end{array}$ & [28] \\
\hline \multicolumn{5}{|c|}{ Chemokine receptor-oriented therapies } \\
\hline CCR2 & $\begin{array}{l}\text { Plozalizumab } \\
\text { (antibody, a.k.a. } \\
\text { TAK-202 and } \\
\text { MLN1202) }\end{array}$ & $\begin{array}{l}\text { Phase II clinical trial } \\
\text { (solid tumor with bone } \\
\text { metastases) }\end{array}$ & $\begin{array}{l}\text { Reduced bone turnover } \\
\text { rates in } 14 \% \text { of } 41 \\
\text { patients, serious toxicity } \\
\text { in } 7 \%\end{array}$ & NCT01015560 \\
\hline CCR2 & $\begin{array}{l}\text { PF-04136309 } \\
\text { (orthosteric small } \\
\text { molecule) }\end{array}$ & $\begin{array}{l}\text { Phase lb clinical trials } \\
\text { (pancreatic cancer) }\end{array}$ & $\begin{array}{l}\text { In combination with } \\
\text { chemotherapy } 16 / 33 \\
\text { patients achieved } \\
\text { objective response. } \\
\text { Toxicity concerns }\end{array}$ & {$[48,49]$} \\
\hline CCR2 & $\begin{array}{l}\text { CCX872-B } \\
\text { (orthosteric small } \\
\text { molecule) }\end{array}$ & $\begin{array}{l}\text { Phase lb clinical trial } \\
\text { (pancreatic cancer) }\end{array}$ & $\begin{array}{l}\text { In combination with } \\
\text { chemotherapy. Currently } \\
\text { ongoing }\end{array}$ & NCT02345408 \\
\hline CCR2 & CNP/siCCR2 (siRNA) & $\begin{array}{l}\text { In vivo BALB/c mouse } \\
4 \mathrm{~T} 1 \text { model of breast } \\
\text { cancer }\end{array}$ & $\begin{array}{l}\text { Reduced CCR2 and } \\
\text { TAM levels, tumor } \\
\text { growth, and metastatic } \\
\text { behavior }\end{array}$ & {$[76]$} \\
\hline CCR4 & $\begin{array}{l}\text { Mogamulizumab } \\
\text { (antibody, a.k.a. } \\
\text { Poteligeo) }\end{array}$ & $\begin{array}{l}\text { Approved clinical use } \\
\text { for cutaneous T cell } \\
\text { lymphoma }\end{array}$ & Currently on the market & \\
\hline CCR4 & $\begin{array}{l}\text { FLX475 (orthosteric } \\
\text { small molecule) }\end{array}$ & $\begin{array}{l}\text { Phase I/II clinical trials } \\
\text { (advanced cancer, } \\
\text { metastatic gastric } \\
\text { cancer, advanced } \\
\text { melanoma) }\end{array}$ & $\begin{array}{l}\text { As monotherapy or in } \\
\text { combination with } \\
\text { anti-PD1 antibody } \\
\text { or anti-CTLA-4 } \\
\text { antibody. Currently } \\
\text { ongoing }\end{array}$ & $\begin{array}{l}\text { NCT03674567, } \\
\text { NCT04768686, } \\
\text { NCT04894994 }\end{array}$ \\
\hline CCR5 & $\begin{array}{l}\text { Maraviroc } \\
\text { (orthosteric small } \\
\text { molecule) }\end{array}$ & $\begin{array}{l}\text { Phase I clinical trials } \\
\text { (metastatic colorectal } \\
\text { cancer) }\end{array}$ & $\begin{array}{l}\text { Reduced tumorigenic } \\
\text { signaling in the TME in } \\
\text { one trial, another trial is } \\
\text { ongoing }\end{array}$ & $\begin{array}{l}{[51,52]} \\
\text { NCT04721301 }\end{array}$ \\
\hline CCR5 & $\begin{array}{l}\text { Leronlimab } \\
\text { (antibody, a.k.a. } \\
\text { PR0140) }\end{array}$ & $\begin{array}{l}\text { Phase } \mathrm{lb} / \mathrm{ll} \text { clinical } \\
\text { trials }\left(\mathrm{CCR} 5^{+}\right. \\
\text {metastatic } \\
\text { triple-negative } \\
\text { breast cancer/solid } \\
\text { tumors) }\end{array}$ & $\begin{array}{l}\text { Clinical studies are } \\
\text { ongoing }\end{array}$ & $\begin{array}{l}\text { NCT04313075, } \\
\text { NCT03838367, } \\
\text { NCT04504942 }\end{array}$ \\
\hline CCR8 & $\begin{array}{l}\text { Anti-CCR8 antibody } \\
\text { (aCCR8) }\end{array}$ & $\begin{array}{l}\text { In vivo BALB/c mouse } \\
\text { CT26 and MC38 } \\
\text { model of colorectal } \\
\text { cancer }\end{array}$ & $\begin{array}{l}\text { Enhanced effector T cell } \\
\text { tumor infiltration and } \\
\text { long-term survival }\end{array}$ & [37] \\
\hline CCR9 & $\begin{array}{l}\text { 91R and 92R } \\
\text { (antibodies) }\end{array}$ & $\begin{array}{l}\text { In vitro/in vivo BALB/c } \\
\text { Rag2 } 2^{-/-} \text {mouse } \\
\text { MOLT-4 model of } \\
\text { leukemia }\end{array}$ & $\begin{array}{l}\text { Reduced in vivo tumor } \\
\text { growth (91R/92R), } \\
\text { angiogenesis (91R) } \\
\text { (leukemia) }\end{array}$ & {$[38,39]$} \\
\hline CXCR1 & Anti-CXCR1 antibody & $\begin{array}{l}\text { In vitro } \mathrm{H} 460 \text { and } \\
\text { MOR/P non-small } \\
\text { cell lung cancer cells }\end{array}$ & $\begin{array}{l}\text { Significantly attenuated } \\
\text { cancer cell proliferation }\end{array}$ & {$[36]$} \\
\hline
\end{tabular}




\begin{tabular}{|c|c|c|c|c|}
\hline Target & Name/type of therapy & $\begin{array}{l}\text { Model/latest stage } \\
\text { clinical trial }\end{array}$ & Key result/comment & Refs/identifiers \\
\hline CXCR1/CXCR2 & $\begin{array}{l}\text { Reparixin (allosteric } \\
\text { small molecule) }\end{array}$ & $\begin{array}{l}\text { Phase II (metastatic } \\
\text { triple-negative breast } \\
\text { cancer) }\end{array}$ & $\begin{array}{l}\text { Well-tolerated and } \\
\text { reduced cancer } \\
\text { stem-cell population }\end{array}$ & [60] \\
\hline CXCR1/CXCR2, & $\begin{array}{l}\text { X1/2pal-i3 (pepducin } \\
\text { targeting intracellular } \\
\text { loop 3) }\end{array}$ & $\begin{array}{l}\text { In vivo NCR Nu/Nu } \\
\text { mouse OVCAR-4 } \\
\text { model of ovarian } \\
\text { cancer. In vivo SCID } \\
\text { mouse PC3, DU145 } \\
\text { and C4-2 xenograft } \\
\text { models of prostate } \\
\text { cancer }\end{array}$ & $\begin{array}{l}\text { Impaired tumor growth } \\
\text { and angiogenesis in } \\
\text { ovarian cancer. Reduced } \\
\text { antiapoptotic protein } \\
\text { expression and tumor } \\
\text { growth in PTEN-deficient } \\
\text { prostate cancer }\end{array}$ & {$[72,73]$} \\
\hline CXCR2 & $\begin{array}{l}\text { AZD5069 (orthosteric } \\
\text { small molecule) }\end{array}$ & $\begin{array}{l}\text { Phase I/II clinical trials } \\
\text { (metastatic head and } \\
\text { neck carcinoma, } \\
\text { pancreatic ductal } \\
\text { carcinoma, and } \\
\text { castration-resistant } \\
\text { prostate cancer) }\end{array}$ & $\begin{array}{l}\text { Low objective response } \\
\text { rate and high toxicity risk } \\
\text { in the pancreatic } \\
\text { carcinoma study. The } \\
\text { other studies are } \\
\text { ongoing }\end{array}$ & $\begin{array}{l}\text { NCT02583477, } \\
\text { NCT02499328, } \\
\text { NCT03177187 }\end{array}$ \\
\hline CXCR2 & $\begin{array}{l}\text { Navarixin (allosteric } \\
\text { small molecule, a.k.a. } \\
\text { SCH-527123 and } \\
\text { MK-7123) }\end{array}$ & $\begin{array}{l}\text { Phase II clinical trial } \\
\text { (non-small cell lung } \\
\text { cancer, } \\
\text { castration-resistant } \\
\text { prostate cancer, and } \\
\text { colorectal cancer) }\end{array}$ & $\begin{array}{l}\text { In combination with } \\
\text { anti-PD1 antibody. } \\
\text { Currently ongoing }\end{array}$ & NCT03473925 \\
\hline CXCR4 & $\begin{array}{l}\text { Mavorixafor } \\
\text { (allosteric small } \\
\text { molecule, a.k.a. } \\
\text { X4P-001, AMD-070, } \\
\text { and AMD-11070) }\end{array}$ & $\begin{array}{l}\text { Phase 1//l clinical trials } \\
\text { (advanced renal cell } \\
\text { carcinoma, } \\
\text { Waldenström's } \\
\text { macroglobulinemia, } \\
\text { and advanced } \\
\text { melanoma) }\end{array}$ & $\begin{array}{l}\text { In combination with } \\
\text { kinase inhibitor, or } \\
\text { anti-PD1 antibody. } \\
\text { Preliminary results } \\
\text { show low toxicity } \\
\text { and increased antitumor } \\
\text { CD8 }{ }^{+} \text {T cell TME levels }\end{array}$ & $\begin{array}{l}\text { [62], } \\
\text { NCT04274738 }\end{array}$ \\
\hline CXCR4 & $\begin{array}{l}\text { Ulocuplumab } \\
\text { (antibody, a.k.a. } \\
\text { BMS-936564 and } \\
\text { MDX-1338) }\end{array}$ & $\begin{array}{l}\text { Phase II clinical trials } \\
\text { (pancreatic } \\
\text { adenocarcinoma, } \\
\text { small cell lung } \\
\text { cancer, and } \\
\text { Waldenström's } \\
\text { macroglobulinemia) }\end{array}$ & $\begin{array}{l}\text { Insufficient therapeutic } \\
\text { response and high } \\
\text { toxicity. Ongoing trial } \\
\text { with Waldenström's } \\
\text { macroglobulinemia }\end{array}$ & $\begin{array}{l}\text { NCT02472977, } \\
\text { NCT03225716 }\end{array}$ \\
\hline CXCR4 & $\begin{array}{l}\text { 238D2 and 238D4 } \\
\text { (nanobodies) }\end{array}$ & $\begin{array}{l}\text { In vitro, Jurkat } \\
\text { leukemia cells }\end{array}$ & $\begin{array}{l}\text { Attenuated } \\
\text { CXCL12-mediated } \\
\text { cancer cell migration }\end{array}$ & [41] \\
\hline CXCR4 & $\begin{array}{l}\text { VUN400-Fc } \\
\text { (nanobody-Fc } \\
\text { construct) }\end{array}$ & $\begin{array}{l}\text { In vitro, CCRF-CEM } \\
\text { leukemia cells }\end{array}$ & $\begin{array}{l}\text { Induced CDC- and } \\
\text { ADCC-mediated cancer } \\
\text { cell killing }\end{array}$ & [42] \\
\hline CXCR4 & $\begin{array}{l}\text { Plerixafor (orthosteric } \\
\text { small molecule, a.k.a. } \\
\text { AMD3100 and } \\
\text { Mozobil) }\end{array}$ & $\begin{array}{l}\text { Approved for clinical } \\
\text { use against } \\
\text { lymphoma and } \\
\text { myeloma }\end{array}$ & $\begin{array}{l}\text { Currently on the } \\
\text { market. Ongoing } \\
\text { Phase II trials for } \\
\text { use in other cancer } \\
\text { types }\end{array}$ & $\begin{array}{l}\text { NCT04177810, } \\
\text { NCT03746080 }\end{array}$ \\
\hline CXCR4 & $\begin{array}{l}\text { Motixafortide } \\
\text { (peptide, a.k.a. } \\
\text { BL8040 and } \\
\text { BKT140) }\end{array}$ & $\begin{array}{l}\text { Phase III (multiple } \\
\text { myeloma). Also in } \\
\text { clinical trials for other } \\
\text { cancer types }\end{array}$ & $\begin{array}{l}\text { Currently ongoing. } \\
\text { Preliminary results show } \\
\text { low toxicity and } \\
\text { enhanced levels of } \\
\text { circulating } \\
\text { hematopoietic stem } \\
\text { cells }\end{array}$ & [64] \\
\hline
\end{tabular}




\begin{tabular}{|c|c|c|c|c|}
\hline Target & Name/type of therapy & $\begin{array}{l}\text { Model/latest stage } \\
\text { clinical trial }\end{array}$ & Key result/comment & Refs/identifiers \\
\hline CXCR4 & LY2510924 (peptide) & $\begin{array}{l}\text { Phase II (metastatic } \\
\text { clear cell renal cell } \\
\text { carcinoma, } \\
\text { extensive-stage } \\
\text { small cell lung } \\
\text { carcinoma) }\end{array}$ & $\begin{array}{l}\text { Low toxicity, but no } \\
\text { improved outcome over } \\
\text { standard treatment }\end{array}$ & {$[68,69]$} \\
\hline CXCR4 & $\begin{array}{l}\text { Balixafortide } \\
\text { (peptide, a.k.a. } \\
\text { POL6326) }\end{array}$ & $\begin{array}{l}\text { Phase III (HER2- } \\
\text { locally recurrent or } \\
\text { metastatic breast } \\
\text { cancer) }\end{array}$ & Currently ongoing & NCT03786094 \\
\hline CXCR4 & $\begin{array}{l}\text { e23sFv-9R/CXCR4si } \\
\text { (siRNA) }\end{array}$ & $\begin{array}{l}\text { In vivo BALB/c nude } \\
\text { mouse HER2 } 2^{+} \\
\text {BT-474 model, breast } \\
\text { cancer }\end{array}$ & $\begin{array}{l}\text { Reduced CXCR4 } \\
\text { expression to inhibit } \\
\text { tumor growth and } \\
\text { metastasis }\end{array}$ & {$[75]$} \\
\hline CXCR4 & $\begin{array}{l}\text { PZ-210 and PZ-218 } \\
\text { (pepducins targeting } \\
\text { intracellular loop } 3 \\
\text { and } 1 \text {, respectively) }\end{array}$ & $\begin{array}{l}\text { In vitro patient cells, } \\
\text { and in vivo NSG } \\
\text { mouse Raji lymphoma } \\
\text { model, leukemia and } \\
\text { lymphoma }\end{array}$ & $\begin{array}{l}\text { Increased survival } \\
\text { (PZ-210). Blocked } \\
\text { migration of lymphoma } \\
\text { cells, and induced } \\
\text { apoptosis in patient cells } \\
\text { in vitro (both) }\end{array}$ & {$[74]$} \\
\hline $\begin{array}{l}\text { ACKR3 } \\
(\mathrm{CXCR7)}\end{array}$ & NB4 (nanobody) & $\begin{array}{l}\text { In vivo nude mouse } \\
22 \mathrm{~A} \text { model, head and } \\
\text { neck cancer }\end{array}$ & $\begin{array}{l}\text { Reduced tumor growth } \\
\text { and angiogenesis }\end{array}$ & [43] \\
\hline
\end{tabular}

${ }^{a}$ Note that for glycomimetics, the chemokine for which the compound was tested is shown. It cannot be ruled out that they also affect other soluble GAG-binders (e.g., other chemokines), as their selectivity was not always reported.

solid cancers, prostate cancer, and hepatocellular carcinoma, among others (NCT03400332, NCT03689699, NCT04050462, NCT04848116, and NCT04123379).

In addition to mAbs, several nanobodies have been developed to block chemokines. These nanobodies are much smaller ( 10 times) than antibodies, which facilitates production, oral administration, and tumor penetration, but results in a short serum half-life [16]. Thus far, nanobodies targeting CCL2, CCL5, CXCL10, CXCL11, and CXCL12 have been reported $[17,18]$. In vitro studies showed chemotaxis inhibition of CXCR3-overexpressing breast cancer cells by a CXCL10 nanobody [17]; as well as chemotaxis inhibition of CXCR3 or CXCR4expressing murine precursor B cell lymphoma cells by nanobodies against CXCL11 and CXCL12 [18]. However, in vivo (pre)clinical data is currently lacking to evaluate the potential of nanobodies as cancer therapeutics. Finally, biologics have been developed to alter chemokine availability by delivering specific chemokines to attract antitumoral immune cells to the TME, as reported previously with CCL16-ChTNT3 (anti-necrotic DNA antibody) and CCL21-B3 (antiPDL1 nanobody) conjugates [19,20].

These illustrative cases suggest that chemokine neutralization with biologics may be a viable anticancer strategy. However, previous work also revealed caveats that require consideration. First, Bonvin et al. demonstrated that some antibodies could recognize both free and GAG-bound chemokines, while others only recognized the free form [21]. Furthermore, the authors found that the antibody targeting the free form elicited a much better therapeutic response compared to the one that recognizes both free and GAG-bound forms. As the vast majority of chemokines are GAG-bound, antibodies that recognize this form will be drained by chemokine-GAG complexes, leaving the free chemokines available to interact and signal via chemokine receptors. 
Thus, this study suggests that anti-chemokine antibodies should be designed to only recognize the free chemokine form to maximize therapeutic effect. Similarly, the surface charge of CCL21 in the aforementioned CCL21-nanobody conjugate required engineering to prevent sequestration to GAGs [20]. Second, studies on the CCL2-CCR2 axis illustrate the risk of cessation-induced complications. Bonapace et al., found that stopping the anti-CCL2 antibody treatment in syngeneic mouse models of metastatic breast cancer resulted in CCL2 expression exceeding pretreatment levels at the metastatic site [22]. This, in turn, translated to a higher incidence of metastasis and higher mortality. A similar increase in metastasis after cessation of anti-CCL2 therapy was reported by Kersten et al., while continued treatment led to metastasis inhibition [23]. Although no exacerbated metastasis was found in Phase I and II clinical trials with the anti-CCL2 antibody Carlumab in prostate cancer patients, CCL2 levels exceeding pretreatment levels were found during administration and after dosing [24,25].

Small molecules

Chemokines can also be neutralized with small molecules. Contrary to biologics, small molecules are easily manufactured, have a smaller size, and high stability that enables oral administration. Yet, thus far only one chemokine, CCL18, has been targeted with a small molecule in a cancer setting [26]. In vivo experiments showed that injection of CCL18 and small-molecule CCL18antagonist SMC-21598 into breast cancer xenografts in mice reduced lung metastasis compared to injection of CCL18 alone. This effect was attributed to the small-molecule binding to CCL18, preventing CCL18 from interacting with its cognate receptors to elicit downstream signaling [26]. In this regard, CCL18 signals via several receptors, including CCR8, membraneassociated phosphatidylinositol transfer protein 3 (PITPNM3 or ACKR6), and G proteincoupled receptor for estrogen (GPR30) [27].

\section{Manipulating chemokine-GAG interactions \\ Modified chemokines}

A second strategy to impair chemokine-induced oncogenic signaling is to interfere with chemokine-GAG interactions. One way to do this is to administer chemokine mutants that are modified to exhibit enhanced GAG-binding and impaired chemokine receptor binding. Indeed, such mutants can disrupt the formation of a chemokine gradient by displacing endogenous chemokines from GAGs and blocking newly-secreted chemokines from binding GAGs. In addition, due to their impaired receptor binding, they prevent the recruitment of chemokine receptor-expressing cells (e.g., cancer cells). This mechanism can yield anticancer effects, as shown by studies with CXCL12 and CCL2, which interact with CXCR4/ ACKR3 and CCR2, respectively [28,29]. Administration of lung-metastasized breast cancer cells, along with an engineered CXCL12 variant (CXCL12 $\alpha$ ), significantly reduced the amount of liver metastases in mice, compared to control [28]. Similarly, mice that were treated with an engineered CCL2 variant (dnCCL2) before and after injection of colon cancer or Lewis lung carcinoma cells, showed significantly reduced lung metastasis compared to untreated mice [29]. In both cases, the antimetastatic effects were attributed to the modulation of the metastatic microenvironment in the target tissue. Notably, the CCL2 mutant only exerted its antimetastatic effect when fused to human serum albumin (HSA), as it otherwise had insufficient serum half-life, presenting an important consideration for future in vivo studies.

\section{Glycomimetics}

The large structural overlap of the GAG binding epitopes and the receptor binding epitopes on chemokines can also be exploited in anticancer therapies. For instance, exogenous GAGs or molecules that mimic GAGs (i.e., glycomimetics), can be used to hinder chemokine ligand-receptor binding. Indeed, Sutton et al. [30] showed that binding of CCL5 to CCR1-expressing hepatocellular 
carcinoma cells could be inhibited by preincubation of CCL5 with the glycomimetics OTR4120 or OTR4131. As a result of this impaired CCL5-CCR1 interaction, CCL5-induced hepatoma cell migration was strongly attenuated in vitro [30]. In subsequent studies, glycomimetics effectively inhibited CXCL12-CXCR4-mediated cell growth and chemotaxis of hepatocellular carcinoma cells in vitro [31]. These precedents suggested a potential for glycomimetics as anticancer strategy, and paved the way for the glycomimetic GMI-1359 to be investigated in prostate cancer preclinical studies, which showed reduced metastasis as monotherapy or in combination with chemotherapy in vivo [32]. After completion of a Phase I trial in healthy volunteers (NCT02931214), GMl-1359 is currently undergoing a Phase lb clinical trial (NCT04197999) to investigate its safety and tolerability in patients with hormone receptor positive breast cancer.

A potential caveat in the design of glycomimetics is their selectivity profile, as exogenous GAGs may naturally target more soluble GAG-binding elements than chemokines. Although this may raise safety concerns, promiscuous GAG-binding might actually be advantageous in some cases. For example, the GAG-mimetic Necuparanib was found to bind vascular endothelial growth factor (VEGF), fibroblast growth factor 2 (FGF2), P-selectin, and CXCL12 [33]. As a result, Necuparanib attenuated VEGF-A and FGF2-induced angiogenesis, P-selectin-mediated tumor cell seeding, and CXCL12-induced cell migration in vitro. This translated to a significant survival benefit in an orthotopic 4T1 murine mammary carcinoma model characterized by spontaneous metastasis [33]. Results from a Phase I clinical trial indicated acceptable safety of Necuparanib in patients with metastatic pancreatic cancer [34]; however, a Phase II clinical trial in metastatic pancreatic ductal adenocarcinoma patients showed no improved outcome upon addition of Necuparanib to standard therapy. Reasons for failure may include an insufficient dose to overcome the TME, the advanced stage of disease, or the presence of intrinsic resistance mechanisms in pancreatic cancer [35].

\section{Modulating chemokine receptors}

Biologics

Chemokine receptors can also be targeted by biologics to block chemokine binding. The therapeutic value of anti-chemokine receptor antibodies is best exemplified by the anti-CCR4 antibody Mogamulizumab, which is currently approved for clinical use in Japan, the United States, and Europe against adult or cutaneous T cell lymphoma. Besides Mogamulizumab, many other anti-chemokine receptor antibodies have been tested in a variety of preclinical studies [12]. Antibodies against CXCR1 [36], CCR8 [37], and CCR9 [38,39] were respectively found to reduce cancer cell proliferation in vitro [36], attenuate tumor growth and improve long-term survival in colorectal cancer mouse models [37], and impair angiogenesis and tumor growth in a xenograft mouse model of human acute lymphoblastic leukemia [38,39]. Furthermore, mAbs against CCR2, CCR4, CCR5, and CXCR4 have advanced to clinical trials as monotherapy or combination therapy in a variety of cancers (Table 1) $[5,12,40]$. As this topic has been extensively reviewed elsewhere [12], we will not cover it further.

Jähnichen et al. were the first to show that chemokine receptors can also be targeted by nanobodies [41]. They engineered two nanobodies, 238D2 and 238D4, which bind different epitopes at the extracellular site of CXCR4. Both nanobodies effectively inhibited CXCL12 binding to CXCR4 as well as CXCL12-mediated migration of leukemia T cells in vitro. Of note, they later engineered a CXCR4-nanobody-fragment crystallizable region (FC) construct, which is similarly able to inhibit CXCR4 but also benefits from ADCC- and CDC-mediated tumor killing in leukemia cells [42]. Moreover, the same group engineered nanobodies directed against ACKR3, such as NB4, which were found to reduce angiogenesis and tumor growth of head and neck cancer cells both in vitro and in vivo [43]. 


\begin{abstract}
Small molecules
The most widely investigated approach to interfere with chemokine ligand-receptor signaling is the use of small molecules that target chemokine receptors. Since these receptors canonically bind proteins rather than small molecules, their orthosteric binding sites are comparatively large, flexible, and highly exposed to the polarity of waters [44]. Thus, it is challenging to target them with small molecules, which generally require deep hydrophobic pockets [45]. Nevertheless, several orthosteric antagonists have been successfully developed, and many of them have been or are currently being tested as potential anticancer therapies in (pre)clinical trials [5]. These include antagonists for CCR2, CCR4, CCR5, CXCR2, and CXCR4 [5,46-49]. Of note, the CXCR4 antagonist Plerixafor has been clinically approved for the treatment of lymphoma and myeloma [50] and is currently being tested for use against other cancer types in Phase II clinical trials (NCT04177810 and NCT03746080). Furthermore, the CCR5 antagonist Maraviroc, which is clinically approved against HIV, may become repurposed for clinical use in metastatic colorectal cancer. Indeed, Phase I clinical trials recently investigated the use of Maraviroc as monotherapy [51], in combination with chemotherapy [52] or with immune checkpoint inhibitors (NCT03274804, NCT04721301). Similarly, other CCR5 antagonists are currently under clinical investigation [53].
\end{abstract}

Small molecules can also bind chemokine receptors at allosteric binding sites. Thus far, four chemokine receptors have been co-crystallized with an allosteric ligand: CCR2 [54], CCR7 [55], CCR9 [56], and CXCR2 [57]. Although several allosteric sites exist, these crystal structures all demonstrate the presence of the same intracellular binding pocket just above helix 8. As reviewed elsewhere [58], targeting chemokine receptors at allosteric sites may have several advantages over orthosteric binding. Most notably, by evading competition, it allows target binding and inhibition even in the presence of abundant chemokines (i.e., insurmountable antagonism). Examples of intracellular allosteric ligands include Reparixin and Navarixin, targeting both CXCR1 and CXCR2. Based on preliminary efficacy in a Phase I trial [59], Reparixin was investigated in combination with Paclitaxel as a treatment for metastatic triple-negative breast cancer in a Phase II clinical trial (NCT02370238). In addition, a recently terminated Phase II study in HER2" breast cancer suggests some reduction in cancer stem cell numbers after treatment with Reparixin as monotherapy [60]. Navarixin is currently being investigated in Phase II clinical trials as part of a combination therapy with an anti-PD1 antibody in non-small cell lung cancer, castration-resistant prostate cancer, and microsatellite stable colorectal cancer (NCT03473925). Of note, the recent CCR7 crystal structure suggests that Navarixin also binds to this receptor [55]; as such, the anticancer effects of this drug might also be mediated by CCR7 [61]. Another example of an allosteric antagonist is Mavorixafor, which binds to an extracellular region of CXCR4 and is currently being tested in clinical trials for advanced renal cell carcinoma (NCT02667886), Waldenström's macroglobulinemia (NCT04274738), and advanced melanoma (NCT02823405). Preliminary results have been disclosed for the study in advanced melanoma, where Mavorixafor was found to be well tolerated, and to increase antitumor $\mathrm{CD} 8^{+} \mathrm{T}$ cell levels in the tumor tissue. Furthermore, the therapeutic effect of Mavorixafor was further enhanced when administered in combination with the anti-PD1 antibody Pembrolizumab [62]. Although only few allosteric ligands have been clinically tested yet, these examples demonstrate the viability of allosteric modulators as anticancer therapies.

Peptidic antagonists

Chemokine receptors can also be modulated by peptide drugs (different from modified chemokines). In the context of cancer, this avenue has mostly been investigated for CXCR4. Out of the several peptide CXCR4 antagonists developed to date [63], LY2510924 has advanced to Phase II, while Motixafortide and Balixafortide to Phase III clinical trials. The clinical use of Motixafortide as a co-therapy has been evaluated in over ten clinical trials spanning Phase I-III 
and across several cancer types, mainly for stem cell mobilization in multiple myeloma [64] and metastatic pancreatic cancer [65]. Balixafortide is currently being tested in a Phase III clinical trial in HER2 ${ }^{-}$metastatic breast cancer (NCT03786094). Finally, the safety of LY2510924 has been demonstrated in several clinical trials, including Phase I and II studies in acute myeloid leukemia [66], advanced solid tumors [67], small-cell lung cancer [68], and advanced renal cell carcinoma [69]; however clinical efficacy has not been demonstrated yet. These cases suggest that peptide antagonists have good toxicity profiles and may provide a viable option for clinical treatment against cancer.

Pepducins are a relatively novel type of peptidic ligands that bind to the intracellular binding site of the target G protein-coupled receptor (GPCR), and therefore likely act as allosteric modulators [70]. In addition, pepducins have desirable pharmacokinetic properties with high bioavailability, and long serum half-lives [71]. As such, pepducins are a promising option in general for novel therapeutics. So far, only three chemokine receptors have been targeted with pepducins: CXCR1, CXCR2, and CXCR4, each in a preclinical setting. The X1/2pal-i3 pepducin, targeting the third intracellular loop of CXCR1 and CXCR2, effectively reduced tumor growth and angiogenesis in a mouse model of ovarian cancer [72]. In another study, X1/2pal-i3 administration was found to reduce CXCL8induced tumor growth and expression of the antiapoptotic protein Bcl-2 in PTEN-deficient prostate cancer xenografts in mice [73]. In addition, the pepducins PZ-218 and PZ-210, which respectively target the first or third intracellular loop of CXCR4, were found to stimulate apoptosis in cancer cells from leukemia patients. Furthermore, these pepducins enhanced Rituximab-induced apoptosis in a Rituximab-resistant cell line, which could not be achieved with the orthosteric antagonist Plerixafor, and prolonged survival in a mouse lymphoma model [74]. Altogether, these results show promise for pepducins as novel anticancer agents.

\section{Small interfering RNA}

Finally, it is also possible to interfere with chemokine-receptor binding by impairing the expression of chemokine receptors with small interfering ribonucleic acids (siRNAs). siRNAs can downregulate chemokine receptor expression directly on tumor cells to prevent oncogenic signaling, or on the TME to impair the recruitment of immunosuppressive cells, such as tumor-associated macrophages

(TAMs). The anticancer value of siRNAs targeting chemokine receptors is illustrated by a CXCR4targeting siRNA, which significantly attenuated tumor growth and metastasis in an in vivo model of HER2 ${ }^{+}$breast cancer [75]. In addition, administration of a CCR2-targeting siRNA resulted in a decrease in CCR2 expression on monocytes, reduced TAM levels, suppressed tumor growth, and attenuated metastatic behavior in a 4T1 murine breast cancer model [76]. However, siRNAs are characterized by poor stability, limited intracellular uptake, and poor localization to target cells [75]. These caveats have been addressed by the coupling of the siRNAs to an anti-HER2 nanobody (ensuring localization to HER2 ${ }^{+}$breast cancer cells) [75] or by their encapsulation in a cationic polymeric nanoparticle (ensuring delivery to monocytes) [76].

\section{Concluding remarks}

With critical roles in tumor growth, metastasis, and TME formation, the chemokine system embodies a key therapeutic target against cancer [3]. Here, we outlined the potential for anticancer therapies that interfere with chemokine function at three critical stages: (i) chemokine availability; (ii) chemokine-GAG binding; and (iii) chemokine receptor binding. These different stages can be targeted by multiple strategies, including siRNA, biologics, peptides, small molecules, and glycomimetics (Figure 2 and Table 1), each of them exhibiting their own advantages and disadvantages (Table 2). Many of these strategies have progressed to clinical trials, and some are even on the market, emphasizing the clinical potential of targeting this system in cancer. Yet, many challenges remain to be addressed in future research in order to improve their likelihood

\section{Outstanding questions}

Which cancer (sub)types and stages will benefit from which specific chemokine intervention strategy?

How can antibodies be designed to only target free, non-GAG-bound chemokines?

What are the underlying principles that define specificity in chemokine-GAG interactions, and how can these be exploited to design therapies that selectively interfere with one chemokineGAG pair?

The expression of some chemokines and their receptors has been successfully repressed. Can this be achieved for other chemokines/receptors as well, and how can this be optimized to only occur at the tumor site?

Are allosteric binding pockets present in all chemokine receptors, and, if so, how can allosteric binding be optimized for one particular chemokine receptor over another?

Would it be clinically advantageous to simultaneously target the chemokine system on several levels in the signaling cascade? For example, can the therapeutic effect be enhanced by combining a GAG-mimetic and a chemokine receptor antagonist?

Can multitarget drugs be rationally designed for currently unexplored combinations of chemokine receptors? And do multitarget drugs always enhance the therapeutic response over targeting chemokine receptors with individual modulators?

How can biased signaling be rationally designed? 


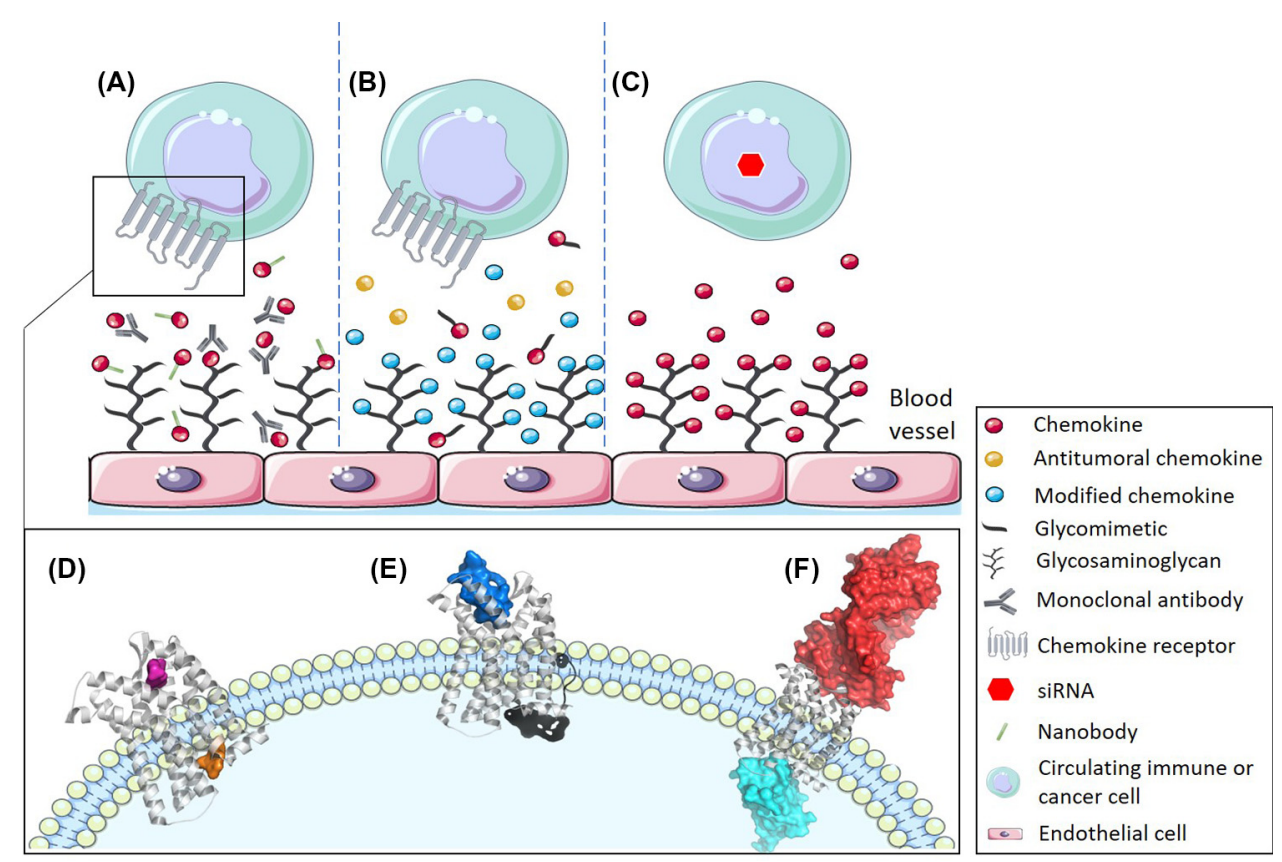

Trends in Pharmacological Sciences

Figure 2. Overview of the therapeutic avenues to modulate the chemokine system in cancer. (A) By neutralizing chemokines (red) with biologics (monoclonal antibodies or nanobodies), a concentration gradient does not develop and/or chemokines are precluded from interacting with their receptor. (B) Administering modified chemokines (blue) with enhanced GAG-binding and an inability to bind chemokine receptors prevents chemokine ligand-receptor binding. Alternatively, exogenous GAGs (glycomimetics) can bind to chemokines to prevent chemokine ligand-receptor binding, or delivery systems can localize antitumoral chemokines (yellow). (C) Chemokine receptor expression can be repressed with short interfering RNA (siRNA) to prevent chemokine signaling even if a concentration gradient develops. (D) Depicts orthosteric (magenta) and allosteric (orange) antagonism of the chemokine receptor (white) by small molecules. (E) Illustrates how chemokine receptors can be antagonized by peptides (blue) or pepducins (black). (F) Shows neutralization of a chemokine receptor by an antibody (red) or nanobody (cyan). This figure was created using elements from Servier medical art. Abbreviation: GAG, glycosaminoglycan.

of clinical success, including the need to increase our understanding of the chemokine system biology in cancer (see Outstanding questions).

Clinical success may also be enhanced by uncovering novel strategies. In this context, it is worth noting that, although not tested against cancer yet, intracellular allosteric ligands have also been synthesized for many other chemokine receptors than those discussed in the main text, including CCR1, CCR4, CCR5, and CX3CR1 [77-80]. Long-residence time antagonists might provide another strategy to inhibit chemokine receptors in an insurmountable manner, such as those described for CCR2 $[81,82]$. Furthermore, the first covalent intracellular antagonist for CCR2 has been recently reported [83], which may improve the therapeutic value via an insurmountable mechanism of action [84]. Another way to improve the clinical efficacy of chemokine receptor inhibitors is to exploit the emerging concept of biased signaling, which has been largely overlooked in drug discovery campaigns. In this regard, Hitchinson et al. [85] found that inhibition of $\beta$-arrestin is responsible for the development of tolerance to CXCR4 antagonist Plerixafor due to an increase of CXCR4 cell surface expression. By contrast, Gai-biased CXCR4 antagonists SEN071 and X-4-2-6 did not affect CXCR4 cell surface expression and thereby evaded tolerance. Furthermore, recent studies have investigated the development of promiscuous chemokine-blocking antibodies [86] and chemokine-blocking peptibodies [87], which aim to 
Table 2. Overview of the key (dis)advantages of the different approaches targeting the chemokine system in cancer

\begin{tabular}{|c|c|c|}
\hline Type of treatment & Advantages & Disadvantages \\
\hline $\begin{array}{l}\text { Antibodies targeting } \\
\text { chemokines }\end{array}$ & $\begin{array}{l}\text { Long serum half-life } \\
\text { Selectively interferes with a single chemokine, whereas } \\
\text { targeting its receptor affects the signaling of all chemokines } \\
\text { that bind the receptor } \\
\text { Can be used as part of pharmacodelivery systems }\end{array}$ & $\begin{array}{l}\text { Difficult and expensive to develop } \\
\text { Cannot be administered orally } \\
\text { Requires additional engineering to prevent targeting of } \\
\text { GAG-bound chemokines } \\
\text { Rebound effect after treatment, which may exacerbate the } \\
\text { pathology }\end{array}$ \\
\hline $\begin{array}{l}\text { Antibodies targeting } \\
\text { chemokine receptors }\end{array}$ & $\begin{array}{l}\text { Long serum half-life } \\
\text { High target specificity } \\
\text { Can elicit antitumor immune responses (ADCC and CDC) }\end{array}$ & $\begin{array}{l}\text { Challenging to generate antibodies against chemokine receptors } \\
\text { Need to be careful not to target a chemokine receptor that is } \\
\text { widely expressed on non-cancer cells }\end{array}$ \\
\hline $\begin{array}{l}\text { Nanobodies (targeting } \\
\text { chemokines or } \\
\text { chemokine receptors) }\end{array}$ & $\begin{array}{l}\text { Can reach more epitopes than antibodies } \\
\text { Cheaper and higher-yielding than production of antibodies } \\
\text { Easier to administer (e.g., through oral administration) than } \\
\text { antibodies }\end{array}$ & $\begin{array}{l}\text { Short serum half-life and general instability may require coupling to } \\
\text { other molecules }\end{array}$ \\
\hline $\begin{array}{l}\text { Small molecule } \\
\text { chemokine neutralizing } \\
\text { agents }\end{array}$ & $\begin{array}{l}\text { Cheaper and quicker to produce than biologics } \\
\text { Easier to administer than biologics }\end{array}$ & $\begin{array}{l}\text { Only a few chemokine-targeting small molecules have been } \\
\text { developed, resulting in little data for rational design approaches. } \\
\text { Requires frequent administration compared to biologics }\end{array}$ \\
\hline Modified chemokines & $\begin{array}{l}\text { Can preclude the formation of a concentration gradient of } \\
\text { tumorigenic chemokines }\end{array}$ & $\begin{array}{l}\text { Requires engineering of the chemokine sequence } \\
\text { May need to be fused with other agents (e.g., HSA) due to low } \\
\text { serum half-life }\end{array}$ \\
\hline Glycomimetics & $\begin{array}{l}\text { Can preclude the formation of a concentration gradient of } \\
\text { tumorigenic chemokines } \\
\text { May attenuate angiogenesis by inhibiting soluble angiogenic } \\
\text { factors, such as VEGF }\end{array}$ & $\begin{array}{l}\text { Difficult to design GAG-mimetics that selectively target one } \\
\text { chemokine over another } \\
\text { May affect unexpected soluble factors other than chemokines }\end{array}$ \\
\hline $\begin{array}{l}\text { Small molecule } \\
\text { chemokine receptor } \\
\text { ligands }\end{array}$ & $\begin{array}{l}\text { Easier to produce, purify, and administer than biologics } \\
\text { Potential for biased signaling to prevent drug tolerance } \\
\text { Orthosteric ligands: } \\
\text { Ample data available for rational design of novel compounds } \\
\text { Allosteric ligands: } \\
\text { Insurmountable activity (i.e., effect even at the presence of } \\
\text { abundant endogenous chemokines) } \\
\text { Ceiling effect (i.e., maximum physiological effect, reducing } \\
\text { toxicity risks) } \\
\text { May be more selective than orthosteric ligands }\end{array}$ & $\begin{array}{l}\text { The exact chemical features that determine biased signaling are } \\
\text { not entirely understood, hindering the rational design of biased } \\
\text { ligands } \\
\text { More prone to off-target induced side-effects compared to } \\
\text { biologics } \\
\text { Orthosteric ligands: } \\
\text { Compete with an abundance of endogenous chemokines } \\
\text { Target a binding site that is large, flexible, and highly polar } \\
\text { Allosteric ligands: } \\
\text { Allosteric binding sites have only been confirmed by crystallization } \\
\text { for a few chemokine receptors, hindering the rational design of } \\
\text { allosteric ligands }\end{array}$ \\
\hline Small interfering RNA & $\begin{array}{l}\text { Can effectively repress the expression of chemokine receptors } \\
\text { on TAMs or tumor cells }\end{array}$ & $\begin{array}{l}\text { Require engineered delivery systems due to poor stability and } \\
\text { intracellular uptake } \\
\text { Difficult to target only the tumor site }\end{array}$ \\
\hline Pepducins & $\begin{array}{l}\text { Likely act as allosteric modulators, thus harboring the } \\
\text { insurmountability and ceiling effect }\end{array}$ & $\begin{array}{l}\text { Their therapeutic use has not been clinically tested } \\
\text { Only three chemokine receptors have been successfully targeted } \\
\text { with pepducins so far }\end{array}$ \\
\hline Peptides & Have largely shown good toxicity profiles in clinical trials & Have mainly been studied for the CXCR4 receptor \\
\hline
\end{tabular}

target multiple chemokines simultaneously. Similarly, several multitarget ligands have been reported for chemokine receptors [88]. The therapeutic potential of such multitarget ligands can be illustrated by the large number of ongoing clinical trials with the dual CCR2/CCR5 antagonist BMS-813160 in various cancer types (NCT03496662, NCT03767582, NCT03184870, NCT04123379, and NCT02996110). Thus, although there is already a wealth of opportunities to target the chemokine system in cancer, new methods are poised to be added to the pharmacological toolbox. While future efforts are still required to optimize these individual methods, this anticipates great potential for the design of future anticancer drugs aimed at the chemokine system. 


\section{Acknowledgments}

T.M.H. is supported by NIH grants R01GM136202 and R01CA254402. L.H.H. and N.V.O.Z. are funded by the Oncode Institute. Research in the De Visser laboratory is funded by the Dutch Cancer Society (KWF10083; KWF10623; KWF13191), Oncode Institute, and The Netherlands Organization for Scientific Research (NWO-VICl 91819616).

\section{Declaration of interests}

K.E.d.V. reports research funding from Roche/Genentech and is consultant for Third Rock Ventures, outside the scope of this work.

\section{References}

1. Bachelerie, F. et al. (2019) Chemokine receptors (version 2019.5) in the IUPHAR/BPS Guide to Pharmacology Database. IUPHAR/BPS Guide to Pharmacology CITE. 2019. Published online November 13, 2019. https://doi.org/10.2218/gtopdb/ F14/2019.5

2. Hughes, C.E. and Nibbs, R.J.B. (2018) A guide to chemokines and their receptors. FEBS J. 285, 2944-2971

3. Lacalle, R.A. et al. (2017) Chemokine receptor signaling and the hallmarks of cancer. Int. Rev. Cell Mol. Biol. 331, 181-244

4. Nagarsheth, N. et al. (2017) Chemokines in the cancer microenvironment and their relevance in cancer immunotherapy. Nat. Rev. Immunol. 17, 559-572

5. Poeta, V.M. et al. (2019) Chemokines and chemokine receptors: new targets for cancer immunotherapy. Front. Immunol. 10, $1-10$

6. Marcuzzi, E. et al. (2019) Chemokines and chemokine receptors: orchestrating tumor metastasization. Int. J. Mol. Sci. 20, 96

7. Ozga, A.J. et al. (2021) Chemokines and the immune response to cancer. Immunity 11, 859-874

8. Vilgelm, A.E. and Richmond, A. (2019) Chemokins modulate immune surveillance in tumorignesis, metastatsis, and response to immunotherapy. Front. Immunol. 10, 6-8

9. Proudfoot, A.E.I. et al. (2017) Glycosaminoglycan interactions with chemokines add complexity to a complex system. Pharmaceuticals 10,70

10. Graham, G.J. et al. (2019) Leukocyte adhesion: reconceptualizing chemokine presentation by glycosaminoglycans. Trends Immunol. 40, 472-481

11. Zahavi, D. and Weiner, L. (2020) Monoclonal antibodies in cancer therapy. Antibodies 9, 34

12. Vela, M. et al. (2015) Chemokine receptor-specific antibodies in cancer immunotherapy: achievements and challenges. Front. Immunol. 6, 12

13. Hoelzinger, D.B. et al. (2010) Blockade of CCL1 inhibits T regulatory cell suppressive function enhancing tumor immunity without affecting T effector responses. J. Immunol. 184, 6833-6842

14. Miyake, M. et al. (2019) Monoclonal antibody against CXCL1 (HL2401) as a novel agent in suppressing IL6 expression and tumoral growth. Theranostics 9, 853-867

15. Bilusic, M. et al. (2019) Phase I trial of HuMax-IL8 (BMS 986253), an anti-IL-8 monoclonal antibody, in patients with metastatic or unresectable solid tumors. J. Immunother. Cancer 7 , 240

16. Mujić-Delić, A. et al. (2014) GPCR-targeting nanobodies: attractive research tools, diagnostics, and therapeutics. Trends Pharmacol. Sci. 35, 247-255

17. Sadeghian-Rizi, T. et al. (2020) Optimization of anti-CXCL10 nanobody expression using response surface methodology and evaluation of its anti-metastatic effect on breast cancer cells. Int. J. Pept. Res. Ther. 26, 1399-1407

18. Blanchetot, C. et al. (2013) Neutralizing nanobodies targeting diverse chemokines effectively inhibit chemokine function. J. Biol. Chem. 288, 25173-25182

19. Li, J. et al. (2003) LEC/chTNT-3 fusion protein for the immunotherapy of experimental solid tumors. J. Immunother. 26, 320-331

20. Fang, T. et al. (2019) Remodeling of the tumor microenvironment by a chemokine/anti-PD-L1 nanobody fusion protein. Mol. Pharm. 16, 2838-2844

21. Bonvin, P. et al. (2017) Antibody neutralization of CXCL10 in vivo is dependent on binding to free and not endothelial-bound chemokine: implications for the design of a new generation of anti-chemokine therapeutic antibodies. J. Biol. Chem. 292, 4185-4197

22. Bonapace, L. et al. (2014) Cessation of CCL2 inhibition accelerates breast cancer metastasis by promoting angiogenesis. Nature 515 , 130-133

23. Kersten, K. et al. (2017) Mammary tumor-derived CCL2 enhances pro-metastatic systemic inflammation through upregulation of ILI $\beta$ in tumor-associated macrophages. Oncoimmunology 6 , e1334744

24. Sandhu, S.K. et al. (2013) A first-in-human, first-in-class, phase study of carlumab (CNTO 888), a human monoclonal antibody against CC-chemokine ligand 2 in patients with solid tumors. Cancer Chemother. Pharmacol. 71, 1041-1050

25. Pienta, K.J. et al. (2013) Phase 2 study of carlumab (CNTO 888), a human monoclonal antibody against CC-chemokine ligand 2 (CCL2), in metastatic castration-resistant prostate cancer. Invest. New Drugs 31, 760-768

26. Liu, Y. et al. (2019) Discovery of CCL18 antagonist blocking breast cancer metastasis. Clin. Exp. Metastasis 36, 243-255

27. Cardoso, A.P. et al. (2021) The immunosuppressive and protumor functions of CCL18 at the tumor microenvironment. Cytokine Growth Factor Rev. 60, 107-119

28. Gschwandtner, M. et al. (2015) Glycosaminoglycan silencing by engineered CXCL12 variants. FEBS Lett. 589, 2819-2824

29. Roblek, M. et al. (2016) Targeting of CCL2-CCR2-glycosaminoglycan axis using a CCL2 decoy protein attenuates metastasis through inhibition of tumor cell seeding. Neoplasia 18, 49-59

30. Sutton, A. et al. (2007) Glycosaminoglycans and their synthetic mimetics inhibit RANTES-induced migration and invasion of human hepatoma cells. Mol. Cancer Ther. 6, 2948-2958

31. Friand, V. et al. (2009) Glycosaminoglycan mimetics inhibit SDF1/CXCL12-mediated migration and invasion of human hepatoma cells. Glycobiology 19, 1511-1524

32. Festuccia, C. et al. (2019) Dual CXCR4 and E-selectin inhibitor, GMI-1359, shows anti-bone metastatic effects and synergizes with docetaxel in prostate cancer cell intraosseous growth. Cells 9,32

33. Zhou, H. et al. (2011) M402, a novel heparan sulfate mimetic targets multiple pathways implicated in tumor progression and metastasis. PLoS One 6, e21106

34. O'Reilly, E.M. et al. (2017) Safety, pharmacokinetics, pharmacodynamics, and antitumor activity of necuparanib combined with nab-paclitaxel and gemcitabine in patients with metastatic pancreatic cancer: phase I results. Oncologist 22, 1429

35. O'Reilly, E.M. et al. (2020) Randomised phase II trial of gemcitabine and nab-paclitaxel with necuparanib or placebo in untreated metastatic pancreas ductal adenocarcinoma. Eur. J. Cancer 132, 112-121

36. Zhu, Y.M. et al. (2004) Interleukin-8/CXCL8 is a growth factor for human lung cancer cells. Br. J. Cancer 91, 1970-1976

37. Villarreal, D.O. et al. (2018) Targeting CCR8 induces protective antitumor immunity and enhances vaccine-induced responses in colon cancer. Cancer Res. 78, 5340-5348

38. Somovilla-Crespo, B. et al. (2018) 92R Monoclonal antibody inhibits human CCR9+ leukemia cells growth in NSG mice xenografts. Front. Immunol. 9, 77

39. Chamorro, S. et al. (2014) Antitumor effects of a monoclonal antibody to human CCR9 in leukemia cell xenografts. MAbs 6 , 1000-1012 
40. Jiao, X. et al. (2021) Leronlimab, a humanized monoclonal antibody to CCR5, blocks breast cancer cellular metastasis and enhances cell death induced by DNA damaging chemotherapy. Breast Cancer Res. 23, 11

41. Jähnichen, S. et al. (2010) CXCR4 nanobodies (VHH-based single variable domains) potently inhibit chemotaxis and HIV-1 replication and mobilize stem cells. Proc. Natl. Acad. Sci. U. S. A. 107, 20565-20570

42. Bobkov, V. et al. (2018) Nanobody-Fc constructs targeting chemokine receptor CXCR4 potently inhibit signaling and CXCR4 mediated HIV-entry and induce antibody effector functions. Biochem. Pharmacol. 158, 413-424

43. Maussang, D. et al. (2013) Llama-derived single variable domains (nanobodies) directed against chemokine receptor CXCR7 reduce head and neck cancer cell growth in vivo. J. Biol. Chem. 288, 29562-29572

44. Kufareva, I. et al. (2017) What do structures tell us about chemokine receptor function and antagonism? Annu. Rev. Biophys. 46 175-198

45. Guo, Z. et al. (2015) Identification of protein-ligand binding sites by the level-set variational implicit-solvent approach. J. Chem. Theory Comput. 11, 753-765

46. Shen, F. et al. (2016) Novel small-molecule CX3CR1 antagonist impairs metastatic seeding and colonization of breast cancer cells. Mol. Cancer Res. 14, 518-527

47. Lee, S. et al. (2015) CCR9-mediated signaling through $\beta$-catenin and identification of a novel CCR9 antagonist. Mol. Oncol. 9 , 1599-1611

48. Nywening, T.M. et al. (2016) Targeting tumour-associated macrophages with CCR2 inhibition in combination with FOLFIRINOX in patients with borderline resectable and locally advanced pancreatic cancer: a single-centre, openlabel, dose-finding, non-randomised, phase $1 \mathrm{~b}$ trial. Lancet Oncol. 17, 651-662

49. Noel, M. et al. (2020) Phase 1 b study of a small molecule antag onist of human chemokine (C-C motif) receptor 2 (PF-04136309) in combination with nab-paclitaxel/gemcitabine in first-line treatment of metastatic pancreatic ductal adenocarcinoma. Invest. New Drugs 38, 800-811

50. De Clercq, E. (2019) Mozobil $\circledast$ (Plerixafor, AMD3100), 10 years after its approval by the US Food and Drug Administration. Antivir. Chem. Chemother. 27, 2040206619829382

51. Suarez-Carmona, M. et al. (2019) CCR5 status and metastatic progression in colorectal cancer. Oncoimmunology 8, e1626193

52. Halama, N. et al. (2016) Tumoral immune cell exploitation in colorectal cancer metastases can be targeted effectively by antiCCR5 therapy in cancer patients. Cancer Cell 29, 587-601

53. Jiao, X. et al. (2019) Recent advances targeting CCR5 for cancer and its role in immuno-oncology. Cancer Res. 79, 4801-4807

54. Zheng, Y. et al. (2016) Structure of CC chemokine receptor 2 with orthosteric and allosteric antagonists. Nature 540, 458-461

55. Jaeger, K. et al. (2019) Structural basis for allosteric ligand recognition in the human CC chemokine receptor 7. Cell 178, 1222-1230.e10

56. Oswald, C. et al. (2016) Intracellular allosteric antagonism of the CCR9 receptor. Nature 540, 462-465

57. Liu, K. et al. (2020) Structural basis of CXC chemokine receptor 2 activation and signalling. Nature 585, 135-140

58. Ortiz Zacarías, N.V. et al. (2018) Intracellular receptor modulation: novel approach to target GPCRs. Trends Pharmacol. Sci. 39, 547-559

59. Schott, A.F. et al. (2017) Phase lb pilot study to evaluate reparixin in combination with weekly paclitaxel in patients with HER-2-negative metastatic breast cancer. Clin. Cancer Res. 23, 5358-5365

60. Goldstein, L.J. et al. (2020) A window-of-opportunity trial of the CXCR1/2 inhibitor reparixin in operable HER-2-negative breast cancer. Breast Cancer Res. 22, 4

61. Salem, A. et al. (2021) CCR7 as a therapeutic target in cancer. Biochim. Biophys. Acta - Rev. Cancer 1875, 188499

62. Andtbacka, R.H. et al. (2018) Abstract 613: X4P-001, an orally bioavailable CXCR4 antagonist, enhances immune cell infiltration and activation in the tumor microenvironment of melanoma. Cancer Res. 78, 613
63. Tahirovic, Y.A. et al. (2020) Small molecule and peptide-based CXCR4 modulators as therapeutic agents. A patent review for the period from 2010 to 2018. Expert Opin. Ther. Pat. 30 87-101

64. Crees, Z.D. et al. (2019) Genesis: phase III trial evaluating BL-8040 + G-CSF to mobilize hematopoietic cells for autologous transplant in myeloma. Future Oncol. 15, 3555-3563

65. Bockorny, B. et al. (2020) BL-8040, a CXCR4 antagonist, in combination with pembrolizumab and chemotherapy for pancreatic cancer: the COMBAT trial. Nat. Med. 26, 878-885

66. Boddu, P. et al. (2018) Initial report of a phase I study of LY2510924, idarubicin, and cytarabine in relapsed/refractory acute myeloid leukemia. Front. Oncol. 8, 369

67. O'Hara, M.H. et al. (2020) Safety and pharmacokinetics of CXCR4 peptide antagonist, LY2510924, in combination with durvalumab in advanced refractory solid tumors. J. Pancreat. Cancer 6, 21-31

68. Salgia, R. et al. (2017) A randomized phase II study of LY2510924 and carboplatin/etoposide versus carboplatin/etoposide in extensive-disease small cell lung cancer. Lung Cancer 105, 7-13

69. Hainsworth, J.D. et al. (2016) A randomized, open-label phase 2 study of the CXCR4 inhibitor LY2510924 in combination with sunitinib versus sunitinib alone in patients with metastatic renal cell carcinoma (RCC). Target. Oncol. 11, 643-653

70. Janz, J.M. et al. (2011) Direct interaction between an allosteric agonist pepducin and the chemokine receptor CXCR4. J. Am Chem. Soc. 133, 15878-15881

71. Tressel, S.L. et al. (2011) Pharmacology, biodistribution, and efficacy of GPCR-based pepducins in disease models. Methods Mol. Biol. 683, 259-275

72. Agarwal, A. et al. (2010) Identification of a metalloproteasechemokine signaling system in the ovarian cancer microenvironment: implications for antiangiogenic therapy. Cancer Res. 70, 5880-5890

73. Armstrong, C.W.D. et al. (2020), Clinical and functional characterization of CXCR1 / CXCR2 biology in the relapse and radiotherapy resistance of primary PTEN-deficient prostate carcinoma. 2, zcaa012

74. O'Callaghan, K. et al. (2012) Targeting CXCR4 with cellpenetrating pepducins in lymphoma and lymphocytic leukemia. Blood 119, 1717-1725

75. Jiang, K. et al. (2015) Targeted delivery of CXCR4-siRNA by ScFv for HER2+ breast cancer therapy. Biomaterials 59, SCFV for
$77-87$

76. Shen, S. et al. (2018) Cationic polymeric nanoparticle delivering CCR2 siRNA to inflammatory monocytes for tumor microenvironment modification and cancer therapy. Mol. Pharm. 15 , 3642-3653

77. Andrews, G. et al. (2008) An intracellular allosteric site for a specific class of antagonists of the CC chemokine G proteincoupled receptors CCR4 and CCR5. Mol. Pharmacol. 73, 855-867

78. Cederblad, L. et al. (2016) AZD8797 is an allosteric noncompetitive modulator of the human CX3CR1 receptor. Biochem. J. 473, 641-649

79. Ortiz Zacarías, N.V. et al. (2018) Pyrrolone derivatives as intracellular allosteric modulators for chemokine receptors: selective and dual-targeting inhibitors of CC chemokine receptors 1 and 2 . J. Med. Chem. 61, 9146-9161

80. Ortiz Zacarías, N.V. et al. (2019) Synthesis and pharmacological evaluation of triazolopyrimidinone derivatives as noncompetitive. intracellular antagonists for $\mathrm{CC}$ chemokine receptors 2 and 5 . J. Med. Chem. 62, 11035-11053

81. Vilums, M. et al. (2013) Structure-kinetic relationships-an overlooked parameter in hit-to-lead optimization: a case of cyclopentylamines as chemokine receptor 2 antagonists. J. Med. Chem. 56, 7706-7714

82. Vilums, M. et al. (2015) When structure-affinity relationships meet structure-kinetics relationships: 3-((Inden-1-yl)amino)-1 isopropyl-cyclopentane-1-carboxamides as CCR2 antagonists. Eur. J. Med. Chem. 93, 121-134

83. Ortiz Zacarías, N.V. et al. (2021) Design and characterization of an intracellular covalent ligand for CC chemokine receptor 2. J. Med. Chem. 64, 2608-2621 
84. Weichert, D. and Gmeiner, P. (2015) Covalent molecular probes for class A G protein-coupled receptors: advances and applications. ACS Chem. Biol. 10, 1376-1386

85. Hitchinson, B. et al. (2018) Biased antagonism of CXCR4 avoids antagonist tolerance. Sci. Signal. 11, eaat2214

86. Angelini, A. et al. (2018) Directed evolution of broadly crossreactive chemokine-blocking antibodies efficacious in arthritis. Nat. Commun. 9, 1461
87. Abraham, M. et al. (2017) Development of novel promiscuous anti-chemokine peptibodies for treating autoimmunity and inflammation. Front. Immunol. 8, 1432

88. Horuk, R. (2009) Promiscuous drugs as therapeutics for chemokine receptors. Expert Rev. Mol. Med. 11, e1

89. Smit, M.J. et al. (2021) The CXCL12/CXCR4/ACKR3 axis in the tumor microenvironment: signaling, crosstalk, and therapeutic targeting. Annu. Rev. Pharmacol. Toxicol. 61, 541-563 